\title{
Psychological Ways of the Development of Intercultural Competence of Pupils in the Field of «Foreign Language Education» (according to the Experience of Education in Foreign Countries)
}

\section{Психологічні шляхи розвитку міжкультурної компетентності учнів у галузі «Іншомовна освіта» (відповідно до досвіду в зарубіжних країнах)}

\section{Eduard Ivashkevych}

Dr. in Psychology, Professor, Rivne State University of the Humanities, Rivne (Ukraine)

ORCID ID: https://orcid.org/0000-0003-0376-4615

Researcher ID: V-8872-2018

E-mail: ivashkevych.e@gmail.com

\section{Едуард Івашкевич}

Доктор психологічних наук, професор, Рівненський державний гуманітарний університет, м. Рівне (Україна)

\section{Oleksandr Hudyma}

Ph.D. in Psychology, Assistant Professor, Kamianets-Podilskyi National Ivan Ohiienko University, Kamianets-Podilskyi (Ukraine)

ORCID ID: https://orcid.org/0000-0001-8244-7284

Researcher ID: F-8900-2019

E-mail: hyduma1979@ukr.net

\section{Олександр Гудима}

Кандидат психологічних наук, доцент, Кам'янець-Подільський національний університет імені Івана Огієнка, м. Кам'янець-Подільський (Україна)

Address for correspondence, e-mail: kpnu_lab_ps@ukr.net Copyright: (C) Ivashkevych Eduard, Hudyma Oleksandr

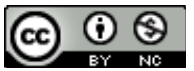
The article is licensed under CC BY-NC 4.0 International (https://creativecommons.org/licenses/by-nc/4.0/)

(C) Ivashkevych Eduard, Hudyma Oleksandr

DOI (article): https://doi.org/10.32626/2227-6246.2020-49.84-105 
DOI: https://doi.org/10.32626/2227-6246.2020-49 2020. випуск 49

The contribution of the author: E. Ivashkevych - 50\%, O. Hudyma - 50\%. Авторський внесок: Е. Івашкевич - 50\%, О. Гудима - 50\%.

\section{ABSTRACT}

The purpose of our research is to show psychological ways of the development of intercultural competence of pupils in the field of "Foreign Language Education" (according to the experience of education in foreign countries).

Methods of the research. The following theoretical methods of the research were used to solve the tasks formulated in the article: the categorical method, structural and functional methods, the methods of the analysis, systematization, modeling, generalization.

The results of the research. In the article we showed in details what exactly means the expression "European development in education": the desire to understand the representatives of different countries and cultures, to overcome prejudice towards them, to recognize their common interests, respecting national ones; openness to different cultures, protection of cultural identity of each person; respect for legal obligations and legal decisions within the paradigm of human rights; the desire to coexist in harmony and to have compromises, allowing the reconciliation of interests of different parties; the protection of freedom, pluralistic democracy, human rights and affairs; the development of the system of production and economic exchanges between the states, which are the factors of individual and social well-being of political stability; the concern for the preservation of ecological balance in Europe and in the whole world; the desire to preserve peace in Europe and in a whole world.

Conclusions. Psychological ways with the aim to develop pupils' intercultural competence were: to provide pupils with information about the socio-cultural plan, which sometimes remains beyond their control; to prove practically that cultural phenomena are most clearly manifested in a certain economic or political perspective; to teach to work with a limited amount of information; to teach to avoid negation and rejection of the phenomena of a foreign-language culture; to have reflexive attitude to their own activity.

In the methodology of teaching foreign languages to the means of training there were put forward certain requirements. So, learning methods with the aim to develop intercultural competence of pupils should: a) to be acted in a form of material and perform its main functions, such as to be means of the activity that ensures the activity of a teacher and the activities of pupils in the

(C) Ivashkevych Eduard, Hudyma Oleksandr DOI (article): https://doi.org/10.32626/2227-6246.2020-49.84-105 
DOI: https://doi.org/10.32626/2227-6246.2020-49 2020. випуск 49

educational process of studying a foreign language; $b$ ) to be oriented towards the purpose of training, that is, with the aim to contribute to the achievement of goals in the process of teaching a foreign language; c) to be instruments of the implementation of methods and techniques used in the educational process, and ensure the management of the activities of a teacher and the activities of a pupil; d) to correspond to the contemporary achievements of the methodology of teaching foreign languages and to ensure the implementation of the latest technologies of teaching a foreign language.

Key words: intercultural competence, representatives of different countries and cultures, openness to different cultures, protection of cultural identity of each person, negation and rejection of the phenomena of a foreign-language culture.

\section{Introduction}

Humanization of teaching process at secondary schools as a strategic direction for the development in a whole of a contemporary European pedagogical process is natural and historically determined phenomenon. It is now a tangible need for educated, creative and active personalities capable for selfimprovement, mutual understanding and interaction with native speakers of different languages and cultures for the benefit of humanity.

The main purpose of teaching foreign languages at secondary schools is to develop the ability of pupils to use a foreign language as the instrument in the dialogue of cultures and civilizations of a contemporary world. This goal involves the interconnected communicative and socio-cultural development of pupils by means of a foreign language in order to prepare schoolchildren for intercultural communication in various spheres of life.

Contemporary concepts of teaching foreign languages are characterized by the desire not only to provide pupils with necessary linguistic means, but also to form a certain cognitive ability, which would create a sense of cultural community with native speakers and gave communication a special (C) Ivashkevych Eduard, Hudyma Oleksandr

DOI (article): https://doi.org/10.32626/2227-6246.2020-49.84-105 
completeness and multidimensionality. However, the assimilation of real facts and conceptual theories of foreign language culture, values, norms, conventions, all that is the content of intercultural competence, is carried out by a disciple, the bearer of concepts, ideas and values learned in the process of socialization of the person his / her own culture. Accordingly, socio-cultural competence, the formation of which is considered now as one of the objectives of teaching foreign languages, in reality becomes a cross-cultural competence due to the inevitable interaction of a native culture with the culture that is being digested (Гончарук \& Онуфрієва, 2018).

The process of studying a foreign language at secondary school should provide four interrelated and equivalent aspects, including cognitive or general education, enriching the spiritual world of the individual, gaining and expanding knowledge of the culture of the country the language of which pupils study. The project of the state general educational standard into the field of «Foreign Language Education» envisages the acquisition of pupils in the process of teaching communicative competence, which, besides language and speech, includes both socio-cultural and intercultural competence. Knowledge of history, geography, economy, state structure and culture, along with the peculiarities of speech and inflectional behaviour of native speakers, is at one level with language knowledge, speech skills and abilities.

Culture is a key concept of our research. In modern scientific issues it is considered as a world of meanings, which components are dominant and, accordingly, the components of culture are knowledge, their values are also regulated. Therefore, culture has a mental character and its reality becomes communicating, which implies, as it is known, the implicit component - so called background knowledge. The certain vision of the world, inherent in each culture, has allowed us to introduce the concept of "picture of the world" as a form of self-organization of cultural space. According to Ch. J. Brum- 
DOI: https://doi.org/10.32626/2227-6246.2020-49

fit, «culture is a great hypnotist» (Brumfit, 1990: 66). This successful metaphor emphasizes that in any cultural system the process of thinking in one way or another one is limited by the general configuration, and each culture has sections of reality that are comprehended in the most complete, less complete or completely unnoticed space. Of course, the human-minded activity of a pupil does not fit into the framework of culture, otherwise there would be no concept of "dynamics», «development», "progress», "creativity», etc.

With the transition of a communicatively oriented foreign language learning, we can not admit that culture becomes the centre, not the periphery of our attention, as it was at the time when it was considered as a system with formal features. The appropriate use of the English language in a social context requires from the pupil not only the knowledge of what "to say", but also "how» and "when to say». And here, as it sounds paradoxical, we again refer to the ancient meaning of the word «culture» - under such conditions we can say about the cultivation of the soul of the disciple. There is no doubt that the possession of two or more languages enriches the person not only with the additional knowledge of other cultures, but also the ability to understand and be tolerant to the representatives of other countries. Europe (and the whole world) after the fall of the Berlin Wall became completely different, not only from the point of view of international politics, but also about cultural diversity. Globalization is such the appropriate term for the economic and political expansion of the superpowers, and at the same time, regional, local sovereign formation is growing from the point of view of counteraction to globalization. Under such conditions, culture becomes a very important concept.

When choosing the means of teaching a foreign language, first of all a textbook, it is necessary to remember their correspondence with the age-specific features of the pupils, their level of language and language training, the realities of contemporary life, the requirements of the current program.

(C) Ivashkevych Eduard, Hudyma Oleksandr

DOI (article): https://doi.org/10.32626/2227-6246.2020-49.84-105 
The purpose of our research is a problem that has become particularly relevant in today's life and, at the same time, extremely controversial. It is about the process of forming the intercultural competence of schoolchildren. This question is new and inadequately analyzed by scientists, methodologists, and teachers - since the motivation for studying a foreign language is a need to communicate in a foreign language environment. The important factor in the attractiveness of the language being studied is its status as the language of interethnic and international communication.

\section{Methods of the research}

The following theoretical methods of the research were used to solve the tasks formulated in the article: the categorical method, structural and functional methods, the methods of the analysis, systematization, modeling, generalization.

\section{Results and their discussion}

The problem of studying the cultural and social peculiarities of the life of people whose language is being studied remains actual for more than two centuries. The profound changes in the socio-political and economic life of European and world countries are increasingly effecting according to the development of their educational systems. The steady tendency of humanization and tolerance of the whole complex of school disciplines should facilitate the pupils' preparation for active life in a changing world, refusal from ideas of ethnocentrism, mastery of contemporary forms of interpersonal and interethnic relations. The World and regional integration has already overcome the block of economic and military-political strategies, led to the formation of a fundamentally new multidimensional socio-cultural space. In this situation, educational systems in many countries have the aim to prepare pupils for cultural, professional and personal communication with representatives of other countries, to familiarize them with their 
traditions, social structure and linguistic culture. Thus, in the educational policy of the European Union it was decided to allocate the Basic Complex of Integrative Disciplines, which should include comparative history, the foundations of law and economics, language and literature, sociology and cultural studies. Such a complex, covering humanitarian disciplines and which have the aim of identifying individuals in national cultures and their connection with universal values, should also give the idea of the "European consciousness", promoting the development of intercultural communication skills.

The school is seen as the instrument of the development of the younger generation in a sense of belonging to European civilization, the disappointment of which in many manifestations of contemporary life there is Europe as a whole. The idea of a European development in education was proclaimed in 1989 in the Recommendation of the Parliamentary Assembly of the Council of Europe III «The European Development in Education» (Dubin \& Olshtain, 1991). Specifically, it emphasizes the need for the formation of a genuine European consciousness of citizens and the inclusion of European ideas into the content of most school disciplines. Let's show in details what exactly means the expression «European development in education»:

- the desire to understand the representatives of different countries and cultures, to overcome prejudice towards them, to recognize their common interests, respecting national ones;

- openness to different cultures, protection of cultural identity of each person;

- respect for legal obligations and legal decisions within the paradigm of human rights;

- the desire to coexist in harmony and to have compromises, allowing the reconciliation of interests of different parties;

- the protection of freedom, pluralistic democracy, human rights and affairs;

(C) Ivashkevych Eduard, Hudyma Oleksandr

DOI (article): https://doi.org/10.32626/2227-6246.2020-49.84-105 
- the development of the system of production and economic exchanges between the states, which are the factors of individual and social well-being of political stability;

- the concern for the preservation of ecological balance in Europe and in the whole world;

- the desire to preserve peace in Europe and in a whole world.

Since until recently, especially at the secondary school level, education depended on the needs and realities of its state. Today the limitations of this approach became apparent. The development of mobility, the presence in the class of a multinational audience, the evolution of the employment market all these factors are sufficient to prove the inconsistency of the concept of a closed school with contemporary realities. Therefore, at the Permanent Conference of the Ministers of Education and Culture of the Land of Germany on December 7, 2018, the idea was expressed that «today the school's task is to revise the rapprochement of peoples and European states and reorganize their relations». "In order to adequately prepare young people for life in the European continent, it is necessary to ensure their knowledge, skills and experience of adaptation to the ever-changing social context, for which purpose pupils have to possess information technologies in order to be able to deal with various sources of various kinds of information and are able to obtain and analyze this information" (Hadley, 1993: 35).

The need to fill the content of school education with sociocultural aspects is recognized today as a priority task both at pan-European and national levels. As the analysis shows, virtually all national programs of European countries in relation to foreign languages contain (de facto) the socio-cultural component of the content of teaching as its main component. However, as a rule, this component is presented as very limited, without taking into account the requirements of time and new development trends, because programs always have cer- 
tain conservatism. This gap is successfully complemented by various projects implemented at the local, school, municipal and international levels. The analysis of available literature on this issue (Honcharuk \& Onufriieva, 2018; Mykhalchuk, 2017) made it possible to compare and generalize the experience of the leading European countries in structuring the socio-cultural component of the content of teaching a foreign language, to determine the directions of its development and to identify influential factors.

First of all, social and political conditions are typical for pupils' environment; they are also very influential, since they determine the choice and interpretation of information and, as a result, provide the relationships between pupil's social culture and the socio-culture of the people whose language is studied. The selection of topics and interpretations of events also depends on the choice of vocabularies, both native and foreign. Schools, as social institutions that prepare young people for further life in the society, have the aim to familiarize their pupils with the doctrine commonly accepted in this society, "who we are and how we see others». To highlight this situation, one can use the peculiarities of structuring the socio-cultural component of the content of teaching English and Ukrainian in Germany. In the years after the Second World War socio-political conditions of the Federal Republic of Germany allowed the educational institutions of the country to cover the Anglo-American society and the way of its life as a model for the younger generation. Accordingly, the educational program in English as the first foreign language envisaged the assimilation of not only linguistics, but also socio-cultural aspects of life. There were deeply studied the monuments of Anglo-American culture, their influence on the development of German and world culture. Famous figures and significant events of British and American history were the focus of contemporary English classes. And after two decades, when West Germany, as a full partner, entered into a military, political (c) Ivashkevych Eduard, Hudyma Oleksandr

DOI (article): https://doi.org/10.32626/2227-6246.2020-49.84-105 
and economic alliance with the Western powers, significant changes were also made in 1963 in the paradigm of educational program of English as a foreign language: «Studying English and American literature should show the cultural heritage of other nations, which, in turn, will contribute to understand the contemporary cultural, political, social and economic life of the population of these countries. Pupils need to be impartially acquainted with the way of life of other peoples, to respect their success and to feel shared responsibility both for the past of Western Europe and for resolving issues on both sides of the borders that possess us with our present» (Canale \& Swain, 1980: 12).

The educational goal of studying English within the conditions of general school of the German Democratic Republic is quite clearly stated in 1978 by New Educational Program. It was emphasized that world imperialism was a system of hostile humanity and a labor-wielding working class under the leadership of the Party and members of this Party have to be ready to the irreconcilable struggle for a happy future. Comparing the way of life of the working class of the German Democratic Republic with the lives of workers in other countries at the lessons of a foreign language the teachers increased the confidence of pupils in the benefits of socialism. If in Germany, English and French were the languages of "friendly» nations, then at the time of the PDR (People Democratic Republic), the people whose native languages were English and French, from the ideological point of view belonged to the enemy camp, and therefore had looked at such characteristic features as uncompromising and impenetrable with relief. As for the study of the Russian language as a foreign language at schools of the German Democratic Republic, the instructions were rather restrained in the assessments and very similar to the West German with respect to the studying English. One can conclude that a socio-political factor, together with the basic conceptual approach to youth preparation for the life in the society, has 
a tremendous impact on the process of studying the socio-cultural component of the content of teaching a foreign language (Celce-Murcia \& Hilles, 1988).

Significantly affecting the local conditions, which include, in particular, the features of a school system, curriculum and programs. For example, you can look at Italy, which is characterized by its flexibility. The Ministry of Education at the state level defines the main directions of education, its goals and objectives to be achieved by pupils of different levels of education. Such recommendations are very useful for teachers who make individual plans of work. In the field of teaching foreign languages, recommendations are required to study the «cultural aspects» of a foreign language, but there were no specific instructions from the didactic point of view. Providing the timing of the Italian National Program's mismatch, the project organizers have found a way to solve this problem with satellite television. In this way, it becomes possible to use a huge amount of information and through awareness of pupils of the peculiarities of native and foreign culture to reduce the level of ethnocentrism, to bring tolerant attitude to representatives of other cultures. This is a goal of the Italian project «Mass Media as a Way to Develop Students' Autonomy».

It was attended by pupils of 35 classes of different ages, teachers of English, German, French and Spanish, who have received special training in courses on the use of satellite television in the process of teaching a foreign language and culture (for 20-50 hours). So, effective recordings of programs were used. Realization of the project had lasted for a year. At the end, the pupils were given a great opportunity to listen to the interview, in which they participated at the first year, answering the questions, and the main purpose of which was to study the level of ethnocentrism of each pupil. Almost all the scholars have come to the conclusion that before the project was completed they had had a superficial knowledge and a (C) Ivashkevych Eduard, Hudyma Oleksandr

DOI (article): https://doi.org/10.32626/2227-6246.2020-49.84-105 
biased attitude to the culture and the country of the language which had being studied.

As the authors of the project emphasize, the cultivation of the person is capable in a case of respecting representatives of other cultures. It is a very important thing of the day. Satellite television provides access to modern authentic materials, facilitates the activation of the learning process, creates the most attractive and flexible learning environment. The pupil feels himself / herself as a researcher and a beginner. The task of the teacher in this process is the development and widespread use at school the methods of cultural analysis, strengthening the connections between «experience» and «acquiring knowledge» (Mykhalchuk \& Kryshevych, 2019).

The Italian experience of structuring and developing socio-cultural component of the content, the essence of which is the decoding of multi-story television plots and the training of obtaining additional information of socio-cultural nature from a variety of sources, and in this way, to increase significantly the level of background knowledge. It is, in our opinion, extremely useful and worthy to follow. And the local conditions that cover the flexibility of the curriculum, the programs and material opportunities at schools, are the main factors which influence the structuring of socio-cultural component of the content of teaching a foreign language at European secondary schools. Indeed, it is up to them to create the attractive and flexible environment for learning, using the latest technical advances (satellite TV, Internet, video and audio), access to authentic materials. And this significantly increases the level of motivation of pupils, gives them the opportunity to understand the differences in native and foreign languages, promotes the education of tolerant attitude towards them among representatives of other cultures, reducing the level of ethnocentrism.

Among the historical and cultural factors, we consider it expedient to highlight, at the first and foremost, the traditions of learning a foreign language. For example, you can 
DOI: https://doi.org/10.32626/2227-6246.2020-49 2020. випуск 49

take Britain, where until the 70-ies of the XX-th century the main was the structural-grammatical approach, and the ability to read the classics of European culture was the aim of teaching foreign languages. The method of their learning was completely the same as the methods of teaching classical languages, especially Latin. Consequently, the school course of teaching a foreign language did not anticipate the development of socio-cultural competence.

Changes that began in the 70's have being continued to this day. Since 1988, a foreign language course was introduced for obtaining a "General Certificate of Secondary Education». Its main purpose was formulated in such a way: "To develop skills and to use effectively a foreign language for communication».

In 1992, a new version of the National Curriculum, the implementation of which is mandatory for public schools, entered into educational process at school. According to this document, all pupils from the age of 11 had to study foreign languages (in Scotland, from 12 years old). Inclusion of a foreign language into the National Curriculum, which is mandatory for all municipal schools in Britain, indicates that the government is aware of the need for the citizens to learn foreign languages for economic prosperity and the fact that the country lags behind in this area of education (Oiler, 1992). However, it should be noted that, despite the government's efforts to intensify the teaching of foreign languages at schools, the situation in this area is still unsatisfactory. The British, in comparison with other inhabitants of the Western European countries, speak foreign languages considerably worse. The main reasons for this are:

- late beginning of studying a foreign language (11-12 years old);

- wrong choice of languages - French as the first foreign language (there is the opinion that it is easier for a person with native English to study German than French);

(C) Ivashkevych Eduard, Hudyma Oleksandr

DOI (article): https://doi.org/10.32626/2227-6246.2020-49.84-105 
- not enough time is spent on studying a foreign language (not more then 2 hours per week for five years);

- insufficient number of foreign language teachers;

- low quality of textbooks, despite their wide choice.

It should be noted that the UK's national specificity of foreign-language education is a low level of reasoning for teaching a foreign language by pupils of both British and nonBritish descent. According to the British themselves, for a long time the word language (лова) was synonymous for them as English (англійська лова). And today British residents do not worry that they will have difficulty in communicating, falling into any part of the world, since English is so widespread that perhaps it is possible to be more surprised at its ignorance than from ignorance of their native language.

British educators regard as a serious problem and the fact that pupils studying this or that foreign language at school may find themselves in a situation where each adult will need knowledge of a completely different language. Therefore, in the UK the school stage of education is understood as preparing for a more serious study of a foreign language in the future. The program of studying a foreign language in the UK has the aim of preparing pupils for independent reading of literary courses and preparation for study abroad. Skills and abilities of a foreign language should help pupils to clarify a large number of issues related to the national, political, social, economic, cultural life of the country had being studied, as well as the comparison and analysis of phenomena, events, processes of the national language life and life abroad.

In addition, one more reason is worth mentioning of one consistent trend: to study the cultural features of the learning a foreign language the people read only by literature, which is clearly not enough for a resident of a contemporary European country. In order to improve the level of foreign-language socio-cultural competence of pupils from Great Britain and France in the period from 1990 to 1993, a joint British-French 
DOI: https://doi.org/10.32626/2227-6246.2020-49

2020. випуск 49

project was organized in which both foreign language specialists and practicing teachers took part. Let's show how this project was carried out by the British side under the leadership of Michel Biram. The basis of the already existing sociology course was used.

\section{Conclusions}

Psychological ways with the aim to develop pupils' intercultural competence were:

- to provide pupils with information about the socio-cultural plan, which sometimes remains beyond their control;

- to prove practically that cultural phenomena are most clearly manifested in a certain economic or political perspective;

- to teach to work with a limited amount of information;

- to teach to avoid negation and rejection of the phenomena of a foreign-language culture;

- to have reflexive attitude to their own activity.

The particular attention was paid to preventing the emergence of new stereotypes that could replace the old ones. The activity has the aim to study five main topics:

1. Family and family holidays in France and in the UK; family composition, relatives; rituals associated with food and meals.

2. Education in France and in the UK.

3. A future profession and the process of socialization in the countries of Europe, prestigious professions, different forms of the activities.

4. National identity and multi-ethnicity in France and Great Britain.

5. The development of empathy among the French population and the attempt to feel like a Frenchman through the widest use of ethnographic technologies for teaching a foreign language.

(C) Ivashkevych Eduard, Hudyma Oleksandr

DOI (article): https://doi.org/10.32626/2227-6246.2020-49.84-105 
As the organizers and participants of the project paradigm, as a result of its implementation, the level of all these components of the foreign-language intercultural competence of pupils has being increased significantly, while in evaluating the determinants have become openness and tolerance, readiness to perceive the phenomena of a foreign language culture and revise its own ethnocentric position. It can be concluded that, despite the lack of perfection of the system of teaching foreign languages at secondary school of Great Britain compared to other European countries, the British experience in developing the socio-cultural component of the content of the curriculum, and this experience is interesting, useful and worthy to follow.

Means of education are the most important component of the foreign language learning process at secondary schools. Definition of teaching aids is the answer to the question «What to teach?" Thus, learning materials can include various material objects that can help the teacher to organize effective learning of a foreign language, and students to master it successfully.

In the methodology of teaching foreign languages to the means of training there were put forward certain requirements. So, learning methods with the aim to develop intercultural competence of pupils should:

a) be acted in a form of material and perform its main functions, such as be means of the activity that ensures the activity of a teacher and the activities of pupils in the educational process of studying a foreign language;

b) be oriented towards the purpose of training, that is, with the aim to contribute to the achievement of goals in the process of teaching a foreign language;

c) be instruments of the implementation of methods and techniques used in the educational process, and ensure the management of the activities of a teacher and the activities of a pupil;

(C) Ivashkevych Eduard, Hudyma Oleksandr DOI (article): https://doi.org/10.32626/2227-6246.2020-49.84-105 
DOI: https://doi.org/10.32626/2227-6246.2020-49 2020. випуск 49

d) correspond to the contemporary achievements of the methodology of teaching foreign languages and ensure the implementation of the latest technologies of teaching a foreign language.

According to such criteria as significance, the purpose and the application of technical equipment means of teaching a foreign language there were divided into: a) basic and auxiliary means; b) for a teacher and for a pupil; c) technical and non-technical ones.

Ideally, all means should be presented in the educationalmethodical complex, which has to teach a foreign language in this or that class of secondary school. In this case, the educational-methodical complex is the main means of learning in its entirety of its components: a textbook, books for a teacher, a linguaphone workshop, computer programs, a set of slides, tapes, audio and video cassettes, tables, etc. Those means that the teacher uses in addition to basic teaching aids are considered as auxiliary ones. This can be a specially selected series of drawings, teacher-distributive training cards, tables, diagrams, as well as illustrated magazines, posters, photographs, etc. All these means and their importance according to the problem of the development of intercultural competence of pupils at secondary schools will be shown and detailed in further our articles.

\section{Literature}

Гончарук Наталія, Онуфрієва Ліана. Психологічний аналіз рівнів побудови комунікативних дій. Психолінгвістика. Психолингвистика. Psycholinguistics: Зб. наук. праць ДВНЗ «Переяслав-Хлельницький пед. ун-т імені Григорія Сковороди». Переяслав-Хмельницький : ФОП Домбровська Я. М., 2018. Вип. 24 (1). С. 97-117. DOI 10.31470/2309-1797-2018-24-1-97-117.

Brumfit, Ch. J. (1990). Communicative Methodology in Language Teaching. Cambridge : Cambridge University Press. 166 p.

Canale, M., \& Swain, M. (1980). Theoretical Bases of Communicative Approaches to a Second Language Teaching and Testing. Applied Linguistics, 1 (1), 1-47.

(C) Ivashkevych Eduard, Hudyma Oleksandr

DOI (article): https://doi.org/10.32626/2227-6246.2020-49.84-105 
Celce-Murcia, M., \& Hilles, Sh. (1988). Techniques and Resources in Teaching Grammar. Oxford : Oxford University Press. 189 p.

Dubin, F., \& Olshtain, E. (1991). Course design: Developing Programs and Materials for Language Learning. Cambridge,: Cambridge University Press. $194 \mathrm{p}$.

Hadley, A. O. (1993). Teaching Language in Context. Boston : Heinle and Heinle Publishers. 532 p.

Honcharuk, N., \& Onufriieva, L. (2018). Communicative needs in the structure of the intercourse process. Fundamental and Applied Researches in Practice of Leading Scientific Schools, 27 (3), 111-116. URL : https://farplss.org/index.php/journal/article/view/373.

Mykhalchuk, Nataliia, \& Kryshevych, Olga (2019). The peculiarities of the perception and understanding of Sonnets written by W. Shakespeare by the students of the Faculty of Foreign Languages. Психолінгвістика. Психолингвистика. Psycholinguistics: Зб. наук. праць ДВНЗ «Переяслав-Хлельницький пед. ун-т ілені Григорія Сковороди». Переяслав-Хмельницький : ФОП Домбровська Я. М. Вип. 26 (1). С. 265-285. DOI 10.31470/2309-1797-2019-26-1-265285.

Mykhalchuk, N. O. (2017). Psychological context of the idea of understanding. Психолінгвістика. Психолингвистика. Psycholinguistics: Зб. наук. праць ДВНЗ «Переяслав-Хлельницький пед. ун-т ілені Григорія Сковороди». Переяслав-Хмельницький : ФОП Домбровська Я. М. Вип. 22 (1). С. 163-175.

Oiler, J. W. (1992). Language Tests at School: A Pragmatic Approach. New York : Longman. 492 p.

\section{References}

Honcharuck, Nataliia, \& Onufriieva, Liana. (2018). Psykholohichnyi analiz rivniv pobudovy komunikatyvnykh dii [Psychological analysis of levels of communicative actions' constructing]. Psykholinhvistyka. Psikholingvistika. Psycholinguistics - Psycholinguistics. Psycholinguistics. Psycholinguistics: Collection of Research Papers of PereiaslavKhmelnytskyi Hryhorii Skovoroda State Pedagogical University, 24 (1), 97-117. Pereiaslav-Khmelnytskyi : FOP Dombrovska Ya. M. DOI 10.31470/2309-1797-2018-24-1-97-117 [in Ukrainian].

Brumfit, Ch. J. (1990). Communicative Methodology in Language Teaching. Cambridge : Cambridge University Press.

Canale, M., \& Swain, M. (1980). Theoretical Bases of Communicative Approaches to a Second Language Teaching and Testing. Applied Linguistics, 1 (1), 1-47.

(C) Ivashkevych Eduard, Hudyma Oleksandr

DOI (article): https://doi.org/10.32626/2227-6246.2020-49.84-105 
DOI: https://doi.org/10.32626/2227-6246.2020-49 2020. ВипУСК 49

Celce-Murcia, M., \& Hilles, Sh. (1988). Techniques and Resources in Teaching Grammar. Oxford : Oxford University Press.

Dubin, F., \& Olshtain, E. (1991). Course design: Developing Programs and Materials for Language Learning. Cambridge : Cambridge University Press.

Hadley, A. O. (1993). Teaching Language in Context. Boston : Heinle and Heinle Publishers.

Honcharuk, N., \& Onufriieva, L. (2018). Communicative needs in the structure of the intercourse process. Fundamental and Applied Researches in Practice of Leading Scientific Schools, 27 (3), 111-116. Retrieved from https://farplss.org/index.php/journal/article/view/ 373.

Mykhalchuk, Nataliia, \& Kryshevych, Olga (2019). The peculiarities of the perception and understanding of Sonnets written by W. Shakespeare by the students of the Faculty of Foreign Languages. Psykholinhvistyka. Psikholingvistika. Psycholinguistics - Psycholinguistics. Psycholinguistics. Psycholinguistics: Collection of Research Papers of Pereiaslav-Khmelnytskyi Hryhorii Skovoroda State Pedagogical University, 26 (1), 265-285. Pereiaslav-Khmelnytskyi : FOP Dombrovska Ya. M. DOI 10.31470/2309-1797-2019-26-1-265-285.

Mykhalchuk, N.O. (2017). Psychological context of the idea of understanding. Psykholinhvistyka. Psikholingvistika. Psycholinguistics - Psycholinguistics. Psycholinguistics. Psycholinguistics: Collection of Research Papers of Pereiaslav-Khmelnytskyi Hryhorii Skovoroda State Pedagogical University, 22 (1), 163-175. Pereiaslav-Khmelnytskyi : FOP Dombrovska Ya. M.

Oiler, J. W. (1992). Language Tests at School: A Pragmatic Approach. New York : Longman.

Івашкевич Едуард, Гудима Олександр. Психологічні шляхи розвитку міжкультурної компетентності учнів у галузі "Іншомовна освіта» (відповідно до досвіду в зарубіжних країнах)

\section{АНОТАЦІЯ}

Мета дослідження - показати й обгрунтувати психологічні шляхи розвитку міжкультурної компетентності школярів у галузі «/ншомовна освіта» (відповідно до досвіду освіти в зарубіжних країнах).

Для розв'язання поставлених у роботі завдань використано такі теоретичні методи дослідження: категоріальний, структурно-функціональний, аналіз, систематизація, моделювання, узагальнення.

(C) Ivashkevych Eduard, Hudyma Oleksandr

DOI (article): https://doi.org/10.32626/2227-6246.2020-49.84-105 
Результати дослідження. У статті детально показано, що саме означає вираз «європейський розвиток в освітній парадигмі»: прагнення зрозуміти представників різних країн і культур, подолати упередженість щодо них, визнати їх спільні інтереси, поважаючи національні; відкритість до різних культур, захист культурної ідентичності кожної людини; дотримання юридичних зобов'язань і правових рішень у парадигмі прав людини; бажання співіснувати в гармонії та йти на компроміси, що дають змогу примирити інтереси різних сторін; захист свободи, плюралістична демократія, права людини та діяльності; розвиток системи виробничого й економічного обміну між державами, які є чинниками індивідуального та соиіального добробуту і політичної стабільності; турбота щодо збереження екологічної рівноваги в Європі та в усьому світі; бажання зберегти мир у європі та у світі загалом.

Висновок. Зазначено, що психологічні шляхи з метою розвитку міжкультурної компетентності учнів передбачають: надавати учням інформацію соціокультурного плану, що нерідко залишається поза контролем школярів; практично довести, що культурні явища найяскравіше виявляються в певній економічній чи політичній перспективі; навчати учнів працювати з обмеженою кількістю інфрормації; навчати школярів уникати заперечення та неприйняття явищ іншомовної культури; срормувати у школярів рефрлексивне ставлення до виконання власної діяльності.

Наголошено, що у методиці навчання іноземних мов до засобів навчання висуваються серйозні вимоги. Отже, методи навчання з метою розвитку міжкультурної компетентності учнів повинні: а) актуалізуватися у формі навчального матеріалу і виконувати його основні функції, наприклад, бути засобами діяльності, що забезпечує активність учителя та діяльність учнів у навчальному процесі вивчення іноземної мови; б) орієнтуватися на мету навчання, що сприятиме досягненню чілей у процесі викладання іноземної мови; в) бути інструментами реалізації методів і прийомів, які застосовуються у навчальному процесі та забезпечують управління діяльністю вчителя й учнів; г) відповідати сучасним досягненням методики викладання іноземних мов і забезпечити впровадження новітніх технологій навчання іноземної мови.

Ключові слова: міжкультурна компетентність, представники різних країн і культур, відкритість до різних культур, захист культурної ідентичності кожної людини, заперечення та нівелювання явищ іншомовної культури.

(C) Ivashkevych Eduard, Hudyma Oleksandr DOI (article): https://doi.org/10.32626/2227-6246.2020-49.84-105 
DOI: https://doi.org/10.32626/2227-6246.2020-49

2020. ВиПУСК 49

Ивашкевич Эдуард, Гудыма Александр. Психологические пути развития межкультурной компетентности учащихся в области «иноязычного образования» (согласно опыту зарубежных стран)

\section{АННОТАЦИЯ}

Цель исследования - показать и обосновать психологические пути развития межкультурной компетентности школьников в области «иноязычного образования» (согласно опыту образования в зарубежных странах).

Для решения поставленных в работе задач использованы следующие теоретические методы исследования: категориальный, структурно-фрункциональный, анализ, систематизация, моделирование, обобщение.

Результаты исследования. В статье подробно показано, что именно означает выражение «европейское развитие в образовательной парадигме»: стремление понять представителей разных стран и культур, преодолеть предвзятость по отношению к ним, признать их общие интересы, уважая национальные; открытость к различным культурам, защита культурной идентичности каждого человека; соблюдение юридических обязательств и правовых решений в парадигме прав человека; желание сосуществовать в гармонии и идти на компромиссы, позволяющие примирить интересы различных сторон; защита свободы, плюралистическая демократия, права человека и деятельности; развитие системы производственного и экономического обмена между государствами, которые являются фракторами индивидуального и социального благосостояния и политической стабильности; забота о сохранении экологического равновесия в Европе и во всем мире; желание сохранить мир в Европе и в мире в челом.

Вывод. Выделены психологические пути с целью развития межкультурной компетентности учащихся: предоставить ученикам информацию социокультурного плана, которая нередко остается вне контроля школьников; практически доказать, что культурные явления наиболее ярко проявляются в определенной экономической или политической перспективе; обучать учеников работать с ограниченным количеством информации; обучать школьников избегать отрицания и неприятия явлений иноязычной культуры; сформировать у школьников рефрлексивное отношение к выполнению собственной деятельности.

(๑) Ivashkevych Eduard, Hudyma Oleksandr

DOI (article): https://doi.org/10.32626/2227-6246.2020-49.84-105 
DOI: https://doi.org/10.32626/2227-6246.2020-49 2020. ВИПУСК 49

Отмечено, что в методике обучения иностранным языкам к средствам обучения предъявляются серьезные требования. Итак, методы обучения с целью развития межкультурной компетентности учащихся должны: а) актуализироваться в форме учебного материала и выполнять его основные функции, например, быть средствами деятельности, обеспечивающей активность учителя и деятельность учащихся в учебном процессе изучения иностранного языка; б) ориентироваться на процесс обучения, что будет способствовать достижению целей в преподавании иностранного языка; в) быть инструментами реализации методов и приемов, применяемых в учебном прочессе, которые обеспечивают управление деятельностью учителя и учащихся; г) отвечать современным достижениям методики преподавания иностранных языков и обеспечить внедрение новейших технологий обучения иностранному языку.

Ключевые слова: межкультурная компетентность, представители разных стран и культур, открытость к различным культурам, защита культурной идентичности каждого человека, отрицание и нивелирование явлений иноязычной культуры.

Original manuscript received April 11, 2020

Revised manuscript accepted May 22, 2020

(C) Ivashkevych Eduard, Hudyma Oleksandr DOI (article): https://doi.org/10.32626/2227-6246.2020-49.84-105 